\title{
Da linguagem à ideologia: contribuições bakhtinianas
}

\author{
Jéssica Nascimento Rodrigues* \\ Mary Rangel**
}

\section{Resumo}

Neste artigo, ancorado substancialmente no pensamento bakhtiniano, objetiva-se realizar um estudo teórico, mediante revisão de literatura, acerca de alguns conceitos fundamentais - linguagem, enunciado, gênero discursivo e ideologia -, evidenciando sua inseparabilidade. Na primeira seção, apresenta-se o pressuposto de que a linguagem é originariamente social e a língua, produto sócio-histórico, em constante mudança. $\mathrm{Na}$ segunda, debate-se o conceito de enunciado como texto, oral ou escrito, concreto, constituidor e organizador da vida coletiva. Na terceira, toca-se na temática dos gêneros discursivos, historicamente situados e organicamente sociais e culturais para, na última seção, desenvolver o conceito de ideologia na interligação constante entre infraestrutura e superestrutura, entre ideologia do cotidiano e oficial. Por fim, discutese, como pano de fundo, o possível comprometimento ético e orgânico do ser humano com a realidade da vida e com os outros.

Palavras-chave: Linguagem. Gênero Discursivo. Ideologia.

* Doutora em Educação pela Universidade Federal Fluminense (UFF). Professora do Colégio Pedro II, Rio de Janeiro.

** Doutora em Educaçáo pela Universidade Federal do Rio de Janeiro (UFRJ). Professora aposentada da Universidade Federal Fluminense (UFF) e Professora visitante da Universidade do Estado do Rio de Janeiro (UERJ). 


\section{Questões Iniciais}

Dentre os inúmeros personagens que compóem a vasta obra de Bertold Brecht (1898-1956) está o sr. Keuner (sr. K. $)^{1}$, que participou por aproximadamente 30 anos de histórias salpicadas, dentre as quais a primeira veio à tona em 1926. Na busca do reconhecimento mais exato acerca do real, no enfrentamento do capitalismo (e do nazismo), essa figura lendária - que viveu o exílio em muitos países e, nele, aproximouse, inclusive, de Walter Benjamin (1892-1940) - produziu também composiçóes em prosa, em um novo modelo, como microcélulas teatrais, na crítica ao romance burguês, espaço que o sr. K. ganha para explicitar o interesse do autor pelo relacionamento entre os sujeitos e pela mudança social, aspectos também constantes na obra de Mikhail Bakhtin (1895-1975), foco deste estudo.

Parte da produção de Mikhail Bakhtin e do Círculo remete à Revolução Russa de 1917, a qual pôs fim ao domínio czarista e deu continuidade a um período de efervescência socialista. O Círculo, segundo Zandwais (2009), tinha o objetivo de contribuir com a construção de uma sociedade emancipada baseada em pressupostos marxistas. Com a morte de Lênin, Stalin tomou o poder e, em busca de uma identidade nacional, tentou estabelecer $o$ grande russo com a ajuda de seu mentor intelectual, Nicolai Marr. Mikhail Bakhtin (2010a) foi deportado nesse período, quando iniciou a escrita de Marxismo e filosofia da linguagem, interessado pela discussão sobre linguagem e ancorado no materialismo histórico e dialético.

Bertold Brecht e Mikhail Bakhtin, além de escreverem em contextos, por um lado, bastante específicos e, por outro, aproximados, buscaram no marxismo um aparato substancial para suas bases filosóficas de produção intelectual e, na literatura, um instrumento tanto de imersão na realidade quanto de propulsão para a transformação. Não se intenciona um aprofundamento dos contextos em que viveram e produziram suas obras, até porque não há espaço aqui para isso, no entanto, vale a pena situá-los como elos coerentes no debate proposto neste artigo que, concentrando-se na obra bakhtiniana, objetiva realizar um estudo teórico, mediante revisão de literatura, acerca de alguns de seus conceitos fundamentais e inextricáveis - linguagem, enunciado, gênero discursivo e ideologia.

A escolha de tais conceitos advém dos objetivos traçados para o estudo desenvolvido no doutorado de uma das autoras deste artigo, cujo tema se reportara à formação de sujeitos críticos letrados por meio do ensino da produção textual escrita em escolas municipais de Niterói (RJ) (RODRIGUES, 2014). Entender a linguagem como produção social e coletiva, por exemplo, foi o pressuposto de que se partiu para a análise do tema, até porque não é possível compreender o pensamento bakhtiniano sem 
antes refletir sobre tal conceito, e a escolha de textos específicos - e consagrados - de Bakhtin (2010a, 2010b, 2011, 2012, 2013) também adveio disso. No caso, para tanto, lança-se mão de alguns fragmentos de Brecht (2006) apenas como mote congruente para o debate proposto, mormente porque fazem refletir, instigam e incomodam.

Entendendo a arte como um intermediário para se pensar a vida e entendendoa, ainda, como uma faceta criadora que compóe o ser humano integral (afinal todos têm uma faceta criadora), lança-se mão de Se os tubaröes fossem homens, de Brecht (2006, p. 53-54), na íntegra:

"Se os tubaróes fossem homens", perguntou ao sr. K. a filha da sua senhoria, "eles seriam mais amáveis com os peixinhos?" "Certamente", disse ele. "Se os tubaróes fossem homens, construiriam no mar grande gaiolas para os peixes pequenos, com todo tipo de alimento, tanto animal como vegetal. Cuidariam para que as gaiolas tivessem sempre água fresca, e tomariam toda espécie de medidas sanitárias. Se, por exemplo, um peixinho ferisse a barbatana, entáo lhe fariam imediatamente um curativo, para que ele náo lhes morresse antes do tempo. Para que os peixinhos náo ficassem melancólicos, haveria grandes festas aquáticas de vez em quando, pois os peixinhos alegres têm melhor sabor do que os tristes. Naturalmente haveria também escolas nas gaiolas. Nessas escolas os peixinhos também aprenderiam como nadar na direção das goelas dos tubaróes. Precisariam saber geografia, por exemplo, para localizar os grandes tubaróes que vagueiam descansadamente pelo mar. O mais importante seria, naturalmente, a formaçáo moral dos peixinhos. Eles seriam informados de que nada existe de mais belo e mais sublime do que um peixinho que se sacrifica contente, e que todos deveriam crer nos tubaróes, sobretudo quando dissessem que cuidam de sua felicidade futura. Os peixinhos saberiam que esse futuro só estaria assegurado se estudassem docilmente. Acima de tudo, os peixinhos deveriam evitar toda inclinaçáo baixa, materialista, egoísta e marxista, e avisar imediatamente os tubarôes, se um dentre eles mostrasse tais tendências. Se os tubarôes fossem homens, naturalmente fariam guerras entre si, para conquistar gaiolas e peixinhos estrangeiros. Nessas guerras eles fariam lutar os seus peixinhos, e lhes ensinariam que há uma enorme diferença entre eles e os peixinhos dos outros tubarôes. Os peixinhos, eles iriam proclamar, são notoriamente mudos, mas silenciam em línguas diferentes, e por isso não podem se entender. Cada peixinho que na guerra matasse alguns outros, inimigos, que silenciam em outra língua, seria condecorado com uma pequena medalha de sargaço e receberia 
o título de herói. Se os tubarões fossem homens, naturalmente haveria também arte entre eles. Haveria belos quadros, representando os dentes dos tubaróes em cores soberbas, e suas goelas como jardins onde se brinca deliciosamente. Os teatros do fundo do mar mostrariam valorosos peixinhos nadando com entusiasmo em direção às goelas dos tubarões, e a música seria tão bela, que a seus acordes todos os peixinhos, com a orquestra na frente, sonhando, embalados nos pensamentos mais doces, se precipitariam nas gargantas dos tubaróes. Também não faltaria uma religião, se os tubaróes fossem homens. Ela ensinaria que a verdadeira vida dos peixinhos começa apenas na barriga dos tubaróes. Além disso, se os tubarôes fossem homens também acabaria a ideia de que os peixinhos são iguais entre si. Alguns deles se tornariam funcionários e seriam colocados acima dos outros. Aqueles ligeiramente maiores poderiam inclusive comer os menores. Isto seria agradável para os tubaróes, pois eles teriam, com maior frequência, bocados maiores para comer. E os peixinhos maiores, detentores de cargos, cuidariam da ordem entre os peixinhos, tornando-se professores, oficiais, construtores de gaiolas etc. Em suma, haveria uma civilização no mar, se os tubarôes fossem homens. (BRECHT, 2006, p. 53-54).

Tendo em vista o objetivo traçado para este texto, essa alusão ao sr. K. vem a calhar. Com os textos deixados em aberto para a participação ativa do leitor (visto que sempre é ativa, se levada em conta a ativa posição responsiva inerente à dialogia bakhtiniana), assim como fizera com as peças teatrais, no texto supracitado, Brecht (2006) se utiliza da metáfora dos peixinhos subservientes aos tubaróes para fazer menção crítica à sociedade de classes. Na comparação dos homens com esses animais, discute alienação, educação, guerra, religião, arte e território como problemáticas inerentes ao que vem a ser a civilização em tempos atuais.

Nesse sentido, no texto Arte e responsabilidade, Bakhtin (2011) discute a fragmentação entre arte e vida, as quais, colocadas em diferentes espaços, separam também o artista (o criador) e o homem, mecanicamente, pois “[...] o homem sai da 'agitação do dia a dia' para a criação como para outro mundo 'de inspiração, sons doces e oraçóes'”. Brecht, cuja vida foi dedicada à arte de modo intenso e integral, conduz esses termos ao seu revés: a conexão arte-vida-ciência. Não obstante seja "[...] mais fácil criar sem responder pela vida e mais fácil viver sem contar com a arte" (BAKHTIN, 2011, p. XXXIV), o insigne alemão, ao considerar o materialismo histórico e dialético como espinha dorsal de suas reflexóes, abre espaço à interpenetração do interno na unidade do indivíduo. E é aqui, nesse embrenhado, que está a responsabilidade/respondibilidade/alteridade de que trata Bakhtin (2011), no 
comprometimento ético e orgânico do ser humano com a realidade da vida e com os outros.

Numa sociedade regida pela ditadura dos tubaróes, o elemento alienaçáo/estranhamento transborda. Os professores-peixinhos têm lá seu lugar reservado para a manutenção da ordem, e as escolas-gaiolas, onde os peixinhos também aprenderiam como nadar na direção das goelas dos tubaróes, funcionam como lócus de reprodução social, evitando, claro, inclinaçóes marxistas. Segundo Bezerra (2012), Bakhtin (2013), quando da descrição acerca do romance monológico ${ }^{2}$, tece sua crítica à reificação do homem, no sentido marxiano, ou seja, direciona uma crítica à redução do homem à coisa na sociedade de classes, e, a partir desse enfoque, mostra que, embora reduzidos a objetos, são geradas vozes e consciências (autoconsciências) resistentes a essa coisificação. $\mathrm{Na}$ análise da obra dostoievskiana, Bakhtin (2013) imprime ao romance polifônico a possibilidade da multiplicidade de vozes, como prova do rompimento com o equilíbrio ideológico instaurado no modo de produção capitalista.

Esse debate sobre ideologia é latente em Se os tubarôes fossem homens (BRECHT, 2006), na resposta do sr. K. à menina, como mecanismo indispensável a um sistema complexo e desigual em que uns comerem os outros é algo natural, afinal o signo ideológico é marcado pelo horizonte histórico-social e, portanto, pelas classes e pelas vozes sociais que o constituem. Nesse ínterim, compreender a natureza social da linguagem é inelutável para investigar a sociedade hodierna, seus limites e suas possibilidades de transformação. E é desse ponto, e dessa problemática, que se inicia este texto-enunciado: "A única maneira de fazer com que o método sociológico marxista dê conta de todas as profundidades e de todas as sutilezas das estruturas ideológicas 'imanentes' consiste em partir da filosofia da linguagem concebida como filosofia do signo ideológico" (BAKHTIN, 2010a, p. 39).

\section{Linguagem}

Não há a pretensão de se desenvolverem todos os conceitos produzidos por/atribuídos a Mikhail Bakhtin. Outrossim, não serão trazidos a debate todos os vieses da Teoria da Enunciaçáo. Pretende-se, sim, açambarcar alguns elementos considerados úteis e, até, indispensáveis para subsidiar caminhos teóricometodológicos para estudos na área da linguagem e da educação, como fora feito na tese de doutorado (RODRIGUES, 2014) e em outras pesquisas recentes, como as de Mello (2011), Brait (2013) e Goulart (2014), apenas para citar algumas. Ademais, vale ressaltar que, como alertam Brait e Melo (2012), muitos termos no campo da linguagem são polissêmicos, inclusive os próprios termos desenvolvidos na obra bakhtiniana, cujos sentidos, posto que foram construídos no conjunto da produção do autor, não se encontram prontos e acabados em um ou outro texto específico. 
De início, é imprescindível salientar que o pressuposto bakhtiniano é a natureza social da linguagem. Como demonstrou Voloshinov (1981), a linguagem não é algo sobrenatural, não é uma invenção, muito menos uma abstração: ela é um produto da atividade humana criativa, social e coletiva, reflete-se em todos os seus elementos - da organização econômica à organização sociopolítica da sociedade que a gerou - e se desenvolve no processo de desenvolvimento das relaçóes materiais como condiçáo necessária à organizaçáo laboral dos seres humanos. Linguagem e trabalho estão, logo, intimamente/organicamente relacionados.

Voloshinov (1981, 1993) e Bakhtin (2010a, 2010b, 2011, 2012, 2013) exprimem como a transformação da organização econômica coopera com a modificação gradual do signo de modo relativamente imperceptível para uma mesma geração humana, posto que, determinada pela organização social do trabalho e pela luta de classes, a linguagem colabora, de forma involuntária, para criar o embriāo da divisáo de classes e de patrimônios na sociedade. A natureza da linguagem - seu aparecimento e seu desenvolvimento - é, portanto, social. Como sua verdadeira essência é o evento social da interação verbal, a linguagem encontra-se materializada/concretizada em um ou em vários enunciados, visto que as relaçóes humanas são o espaço próprio da linguagem, são seu corpo, sua essência e seu modo de existência, porquanto não há expressão humana livre do social, ou seja, sem uma situação, sem uma orientação social e sem participantes próximos ou distantes.

Se a linguagem tem natureza social e coletiva, a língua não é um código abstrato, não é estrutura superior estável, não é um sistema uniformizador supremo. A língua, que evolui ininterruptamente por ser um fenômeno histórico, “[...] dura e perdura sob a forma de um processo evolutivo contínuo. Os indivíduos não recebem a língua pronta para ser usada; eles penetram na corrente da comunicação verbal" (BAKHTIN, 2010a, p. 111). É a interação verbal, portanto, fenômeno social fundamental e original, que constitui a realidade da língua, e náo o sistema abstrato de formas linguísticas; é a comunicação verbal concreta entre o falante, o outro e o objeto, uma tríade viva, uma tríade humana.

Ainda sobre a questão da língua, diferenciando classe social e comunidade semiótica, Bakhtin (2010a, p. 47, grifos do autor) elucida que:

Classe social e comunidade semiótica não se confundem. Pelo segundo termo entendemos a comunidade que utiliza um único e mesmo código ideológico de comunicação. Assim, classes sociais diferentes servem-se de uma só e mesma língua. Consequentemente, em todo signo ideológico confrontam-se indices de valor contraditórios. $\mathrm{O}$ signo se torna a arena onde se desenvolve a luta de classes. 
Aqui, pode-se visualizar a base materialista conferida à interpretação de linguagem, língua e signo, cujo peso pende para a sobreposiçâo do social e do coletivo ao individual e da infraestrutura à superestrutura. Bakhtin (2010a) esclarece que uma língua, vista como código superior e intangível, é colocada acima das classes sociais, igualando-as, e o signo, nesse âmbito, torna-se algo monovalente, isento de índices sociais de valor. Entretanto, o autor aprofunda essa questáo ao registrar que a evoluçáo do horizonte apreciativo de um dado grupo social, de uma determinada classe social, que acompanha a evolução semântica de uma língua, é determinada pela infraestrutura econômica dialeticamente. No caso, uma língua materna, código ideológico de comunicação utilizado por uma mesma comunidade, possui sim uma composição vocabular e uma estrutura gramatical específica, mas os sujeitos que se utilizam dela não a aprendem por intermédio de manuais, mas sim pela prática, pelos usos, pelas enunciaçóes concretas desdobradas no contexto social.

Segundo Zandwais (2009, p. 105), ao comentar a obra Marxismo e filosofia da linguagem, "[...] toda língua se regula pela açáo contínua e ininterrupta de forças contraditórias permeadas por variaçóes dialetais e por registros discursivos que se impregnam de diferentes 'acentos' ou valores". Desse modo, a linguagem existe na organização social dos sujeitos, na infraestrutura e na superestrutura como realidade material; as línguas existem na práxis, nas relaçôes humanas coletivas e interativas. Por esse motivo, Bakhtin (2010a) afirma ser uma fiçãao pensar a língua como um sistema de normas rígidas, como se fosse regida abstratamente por algo superior, exterior e estável.

\section{Enunciado-Texto}

Sob o peso da relação dialética entre infraestrutura e superestrutura, feita a defesa da linguagem como originariamente social e da língua como produto sóciohistórico em constante mudança, em constante devir, discute-se o texto, oral ou escrito, como enunciado concreto que constitui e organiza a vida coletiva. Ademais, salienta-se que, na composiçáo do enunciado-texto, questão deveras complexa, os signos (entendidos aqui, sobretudo, como palavras) que o compóem não são isentos de índices sociais de valor, visto que sáo objeto de disputas ideológicas que refletem e refratam a realidade material, marcadas por características sociais e de classe.

É possível, agora, indicar o peso da influência do pensamento bakhtiniano nos estudos que coadunam linguagem e educação. O caso da Linguística Textual, por dentro do campo da Linguística, área que tomou vulto nas últimas décadas com as Teorias do Texto, inobstante existam várias correntes, é um exemplo. De maneira geral, ela preocupa-se em investigar o texto como uma unidade básica de manifestação da linguagem e não mais, como fora numa concepção mais "tradicional", como a palavra, ou como a frase isolada, ou como 
um emaranhado de frases fragmentadas. Nesse campo de estudos linguísticos, pesquisa-se o que faz de um texto ser um texto, ou seja, quais são os elementos encarregados de lhe conferir textualidade, questáo que se infiltra nas escolas, sobretudo quando se trata do ensino de línguas.

Já que todo texto é atravessado pelo discurso humano e que por trás de todo texto sempre há vozes (BEZERRA, 2013), começa-se a contextura do debate pela caracterização do discurso como biface, pois nele reside a ambivalência locutorouvinte, porque o texto é construído na perspectiva da enunciação. Para Bakhtin (2013), nas palavras de Bezerra (2013, p. XVII, grifo nosso), “[...] o texto é um enunciado, o diálogo entre textos é um diálogo entre enunciados, e por trás do enunciado existe o falante, o sujeito dotado de consciência”.

Contudo, embora a presença desses sujeitos seja simultânea e dialógica, a expressão linguística volta-se para a direção do ouvinte que, mesmo ausente, ativamente apresenta uma percepção avaliativa sobre o enunciado. Consoante Voloshinov (1981), essa orientação em direção ao outro também é social, levadas em consideração a relação hierárquica e social existente entre os interlocutores (a situação financeira, a profissão, a função, dentre outros elementos) e a composição da comunicação verbal numa tríade: o falante/locutor/autor, o outro/receptor/destinatário e o objeto/tema.

Com isso, a expressão elementar de uma necessidade biológica/natural recebe inevitavelmente uma coloraçáo sociológica e histórica, de época, de ambiente social, de posiçáo de classe do falante e da situaçáo real e concreta em que acontece a enunciação, enfim, a expressão é de caráter social e é também biface - porque possui um conteúdo interior e uma objetivação exterior (para outrem ou para si mesmo), ou seja, um signo interior e um signo exterior -, e esta é uma condição necessária para a compreensão verbal (além da transmissão do signo): a compreensão do signo e a resposta a ele.

No entanto, vale reforçar que "Não é atividade mental que organiza a expressão, mas, ao contrário, é a expressâo que organiza a atividade mental, que a modela e determina sua orientaçáo" (BAKHTIN, 2010a, p. 116, grifo do autor). A expressão de que trata é, dessa forma, determinada pela situação concreta, pelas condiçôes reais de enunciação, e é por isso que, a cada enunciação, um enunciado jamais será o mesmo, posto que é social e histórico, organizado de fora para dentro. De acordo com Brait e Melo (2012), por exemplo, uma frase pode se realizar em um número infinito de enunciados únicos em situaçôes diversificadas.

Instigado por embates teóricos, sobretudo no campo da Linguística, e pelas condiçóes de produção de sua obra, Bakhtin (2010a, 2011) dispóe de um paralelo não excludente entre o enunciado e a oração. Reforça que o enunciado, como visto, é unidade da comunicação discursiva, e não a oração, que é unidade da língua e tem 
fronteiras gramaticais, embora esta contribua com a produção do enunciado concreto, ou, em outros termos, do texto. A oração, por um lado, só é afirmação real no contexto do enunciado, pois fora dele ela se esvazia de sentido; por outro lado, o enunciado, um elo na cadeia da comunicação discursiva, é determinado pelo elemento semântico-objetal e, ao mesmo tempo, pelo elemento expressivo, é um todo organicamente vinculado à situação, à orientação social e aos participantes da comunicação verbal.

Da mesma forma que chama atenção para as diferenças essenciais entre a oração e o enunciado, para Bakhtin (2010a) há diferenças fundamentais entre signo e sinal. O signo não é uma forma linguística, como um sinal, pois um signo é um signo porque tem uma mobilidade específica, ou, ainda, um signo é um signo porque é a palavra em seu sentido particular, dependente de uma situação específica. Pode-se concluir, desse modo, que o sinal está para a oração, assim como o signo está para o enunciado; no entanto, sinal/oração e signo/enunciado funcionam imbricados.

Como elemento que compóe o enunciado, o signo (ou a palavra), segundo Bakhtin (2010a, p. 135, grifo do autor), é neutro, mas não porque isento de índices sociais de valor, afinal "A multiplicidade das significaçôes éo indice que faz de uma palavra uma palavra”. O signo, de fato, é neutro porque é aberto, podendo ser preenchido de diversos sentidos na dependência do verbal e do extraverbal em sua dupla materialidade: em síntese, o signo é físico-material e sócio-histórico.

Destarte, reitera-se que o enunciado, em sua multiplicidade de sentidos e de vozes, é formado por uma parte verbal e uma parte extraverbal, a qual possui três aspectos subentendidos: (a) o tempo e o espaço do evento comunicativo (o cronotopo ou o espaço comum dos interlocutores); (b) o objeto do enunciado (o tema ou o conhecimento e a compreensão comum da situação por parte dos interlocutores); e (c) a posição dos interlocutores diante do fato (a orientação social ou a avaliação da situação também por parte dos interlocutores) (BRAIT; MELO, 2012). Desse modo, respectivamente, todo enunciado tem situação, sentido e auditório ou participantes.

Nesse viés, no enunciado concreto, composto por um universo de signos ${ }^{3}$, encontra-se o processo interativo. Em primeiro lugar, no que tange ao cronotopo/à situaçáo do evento comunicativo, o verbal e o não verbal integram a situação stricto sensu, consideradas as condiçóes imediatas, e o contexto histórico lato sensu, consideradas as condiçôes mediatas. Em segundo lugar, no que tange ao auditório/aos participantes, o enunciado tem sempre autor e destinatário, mesmo que este seja virtual.

Nesse ínterim, no que toca tanto o autor/locutor quanto o receptor/destinatário, Bakhtin (2010a, 2011) considera como auditório do enunciado a presença dos que fazem parte de uma dada situação, os interlocutores, porquanto o 
enunciado é um elo na cadeia discursiva, marcado pela alternância de vozes, marcado dialogicamente pela presença do outro: "Cada enunciado é um elo na corrente complexamente organizada de outros enunciados" (BAKHTIN, 2011, p. 272). O enunciado, dessa arte, é expressão verbal, é a real unidade da cadeia discursiva, cujos componentes fundamentais são: a entonação (expressão fônica da avaliação social), a escolha lexical e sua disposição em seu interior.

Lembra Bezerra (2013) - numa crítica ao entendimento de intertextualidade na perspectiva da linguista Julia Kristeva -, que, como todo texto é um enunciado, a interação não se dá entre textos, numa perspectiva puramente linguística, mas sim entre vozes, numa perspectiva extralinguística. Essa questão fica clara no livro Problemas da Poética de Dostoiévski quando Bakhtin (2013) analisa o romance polifônico enfatizando o discurso como língua em sua integridade concreta.

Desse modo, há a natureza ativamente responsiva de todo o enunciado vivo, tendo em vista que toda compreensão é prenhe de resposta, embora esta nem sempre seja imediata. Se compreender é opor à palavra uma contrapalavra, em virtude da orientaçáo social dos participantes da interação verbal, toda enunciação tem uma orientaçáo apreciativa - ou seja, aqui se derruba a equaçáo de que um locutor enunciaria para que o receptor, passiva e linearmente, recebesse um enunciado de sentido fixo.

Nesse sentido, na comunicação discursiva viva, a palavra, como signo, claro, existe em três aspectos: como palavra neutra (porque se enche de sentido arraigada no contexto mediato e imediato), como palavra do locutor e, óbvio, como palavra do outro (como contrapalavra). Todavia, em razão de a palavra do locutor ser repleta de palavras dos outros e de tons valorativos assimilados e/ou reelaborados, o enunciado é composto por tonalidades dialógicas, é um elo precedente e subsequente na cadeia da comunicaçâo discursiva na relação estilístico-composicional e semântico-objetal com outros enunciados, que, sempre novos, nunca se repetem (BAKHTIN, 2011).

De acordo com Miotello (2012), nessa conjuntura, as palavras são, ao mesmo tempo, agentes e memórias sociais, tecidas por uma multidão de fios ideológicos, contraditórios entre si. E, como se apresentam assim em todos os campos das relaçóes humanas, constituindo e sendo por eles constituídas, as palavras - e o enunciado figuram-se como terreno dos conflitos sociais.

Comparando o trabalho com a argila, um material físico, e o trabalho com a palavra, um material verbal, Voloshinov (1993) aponta que esta tem um sentido, diferente daquela, que nada significa. Com isso, conclui que é importante conhecer a essência da linguagem, produto da atividade humana coletiva em estreita relação com a organização econômica e sociopolítica da sociedade. Desse modo, também inspirado em Bakhtin, Geraldi (2009, p. 18, grifo nosso) salienta que a linguagem, cujo lugar 
original é a interação verbal, é atividade constitutiva, é "[...] trabalho social e histórico seu [do ser humano] e dos outros e para os outros e com os outros".

De fato, o social precede o individual e o mundo interior depende do exterior. Por exemplo, ao explicar que os dois componentes do comportamento integral humano são o discurso interior e o discurso exterior, reforça que tais elementos são objetivos e materiais (BAKHTIN, 2010a, 2012). Em O Freudismo: um esboço crítico, Bakhtin (2012) afere um veemente crítica ao célebre psicanalista Sigmund Freud (1835-1930) e, por extensão, à psicologia individual, no que toca a fundamental determinaçáo dos fatores objetivo-sociais sobre o componente verbal do comportamento: "[...] todo o verbal no comportamento do homem (assim como os discursos interior e exterior) de maneira nenhuma pode ser creditado a um sujeito singular tomado isoladamente, pois não pertence a ele, mas sim ao seu grupo social" (BAKHTIN, 2012, p. 86).

Dessa maneira, defende-se que todo texto é um enunciado (coletivo e social) repleto de vozes, pois, segundo Bakhtin (2011), texto é um conjunto coerente de signos/palavras e só tem vida no contato com outros textos. Para ele, no entanto, nenhum texto pode ser traduzido por inteiro, assim como nem tudo pode ser substituído por palavras: oral ou escrito, o objeto-texto não comporta em si um único texto, mas abarca muitos textos, e é aqui que entra novamente a questão da dialogia, $\mathrm{e}$ não da intertextualidade em sentido meramente linguístico. De acordo com Castro (2009, p. 122), na integração de vozes que refletem e refratam ideologicamente os temas do enunciado, "[...] grande parte de nossas interaçóes, principalmente as relacionadas com a complexidade da construçáo da escrita, opera o tempo todo com a virtualidade da interlocução".

Toda enunciação monológica, como o próprio ato da escrita individual, é constituinte da comunicação verbal; assim, toda enunciação, mesmo a escrita, é uma resposta apreciativa a algo, ainda que a atividade mental oscile entre a atividade mental do eu e a atividade mental do nós. Vale reforçar que não se encontram as raízes da enunciação de um sujeito limitadas ao organismo individual singular, já que a própria tomada de consciência sobre si mesmo se dá sob determinada norma social, o que Bakhtin (2012) denomina socialização de si mesmo e do seu eu. Todo texto (entendido aqui como enunciado concreto) é dependente do locutor e do receptor (mesmo que virtual) - é dependente do auditório da enunciação -, da situação (considerados o espaço e o tempo ou, em outras palavras, o cronotopo) e das vozes que o atravessam, como enunciados de outros (como fenômeno de dialogia/relaçóes dialógicas). 


\section{Gêneros Discursivos: gêneros da vida}

Forma e conteúdo

O sr. K. observava uma pintura na qual alguns objetos tinham uma forma bem arbitrária. Ele disse: "A alguns artistas acontece, quando observam o mundo, o mesmo que aos filósofos. Na preocupação com a forma se perde o conteúdo. Certa vez trabalhei com um jardineiro. Ele me passou uma tesoura e me disse para cortar um loureiro. A árvore ficava num vaso e era alugada para festas. Por isso tinha que ter a forma de uma bola. Comecei imediatamente a cortar os brotos selvagens, mas náo conseguia atingir a forma de uma bola, por mais que me esforçasse. Uma vez tirava mais de um lado, outra vez de outro. Quando finalmente ela havia se tornado uma bola, esta era pequena demais. $\mathrm{O}$ jardineiro falou, decepcionado: 'Certo, isto é uma bola, mas onde está o loureiro?'”. (BRECHT, 2006, p. 33).

Pede-se aqui mais uma licença literária. Toma-se novamente um texto, na íntegra, da coletânea Histórias do sr. Keuner, mote para discussão sobre gênero. No caso, a prosa, em toda a obra de Bertold Brecht (2006), tem um caráter ímpar. Entretanto, esse certo novo modelo de prosa, no combate ao romance burguês, além de articulaçáo com outros modelos, como com a literatura chinesa, parece inexprimível ou inclassificável, talvez como uma mescla de gêneros ou, talvez, como um gênero cuja mescla lhe é um atributo.

Nesse sentido de mescla, de heterogeneidade, Bakhtin (2013), segundo Machado (2012), interessou-se pelo romance, pois nele encontrou a representaçáo da voz na figura dos homens que falam diante do mundo, ou seja, o romance como gênero de muitas possibilidades tanto de discursos quanto de gêneros. Os gêneros discursivos surgem, então, dessa linguagem prosaica, que une diálogos cotidianos (como os gêneros discursivos primários) às enunciações institucionais, artísticas, científicas e filosóficas (como os gêneros discursivos secundários), ainda que os primeiros invadam os segundos. Como também se vê representado na obra brechtiana, a prosa está na esfera dos discursos heterogêneos que, com o desenvolvimento dos gêneros discursivos ao longo na História, está em constante transformação com a evolução das práticas emergentes das interaçóes dialógicas e, junto a isso, com a transformação da infraestrutura em articulação com a superestrutura.

Toca-se nessa questão, então, para se pensar no conceito de gênero discursivo em interligação com a discussão anterior. De fato, nesse sentido, todo enunciado se apresenta como um gênero porque todos os enunciados pelos quais se enuncia possuem 
uma forma relativamente estável não desatrelada de seu conteúdo - como muito bem conota a metáfora criada pelo sr. K. do trabalho do jardineiro que, ao modelar um loureiro, perde o que realmente é um loureiro. É por isso que os sujeitos lançam mão dos gêneros por toda a vida, com segurança e habilidade, não obstante a compreensão sobre sua existência seja complexa.

Nesse sentido, ao discutir a psicologia do corpo social, Bakhtin (2010a) enfatiza que precisam ser considerados dois aspectos: do ponto de vista do conteúdo (os temas num momento temporal específico) e do ponto de vista dos tipos e das formas do discurso (os quais dão forma aos conteúdos). Como um loureiro, o tema e a forma estão intimamente relacionados - sua separação só se dá abstratamente. Assim, o autor inicia uma definição acerca dos gêneros:

[...] cada época e cada grupo social têm seu repertório de formas de discurso na comunicação socioideológica. A cada grupo de formas pertencentes ao mesmo gênero, isto é, a cada forma de discurso social, corresponde um grupo de temas. Entre as formas de comunicaçáo (por exemplo, relaçáo entre colaboradores num contexto puramente técnico), a forma de enunciaçáo ("respostas curtas" na "linguagem de negócios") e enfim o tema, existe uma unidade orgânica que nada poderia destruir. Eis por que a classificação das formas da enunciação deve apoiar-se sobre uma classificação das formas da comunicą̧ão verbal. Estas últimas são inteiramente determinadas pelas relações de produção e pela estrutura sociopolítica. (BAKHTIN, 2010a, p. 44, grifo do autor).

Por esse motivo, há diferentes tipos de comunicação social a que correspondem diferentes tipos de enunciados: são estes os gêneros utilizados, criados e recriados, pelos sujeitos reais em condiçôes igualmente reais de existência. O gênero é, nesse sentido, cada um dos tipos de comunicação social organizada, que constrói e completa, de modo específico, a forma gramatical e estilística do enunciado, assim como a estrutura de onde ela se destaca, e, desse modo, enunciado e gênero, estrutura-tipo, são inseparáveis. Se são inseparáveis, se o enunciado está intrínseco ao sujeito que dele lança mão, Bakhtin (2011) adita que é possível conhecer uma pessoa pelos gêneros conhecidos por ela. No entanto, a obra da criação cultural, ao contrário do que pensa a orientaçáo burguesa, não pode ser determinada por estados individuais ou por vivências psíquicas do criador, até porque esses aspectos individualizados são ideológicos (BAKHTIN, 2012).

Os gêneros discursivos são estruturas-tipo híbridas, heterogêneas, pois são esferas de uso da linguagem. Suas características típicas não os estabilizam no tempo e 
no espaço, posto que, com traços particulares, os gêneros só têm sua forma acabada em cada situação vivida, que também jamais se repete, assim como os enunciados. Os gêneros discursivos, dessarte, são organizadores dos discursos, moldando-os sobremaneira, daí a sua diversidade determinada por suas diversas funçóes dependentes da situação, da posiçấo social e das relaçôes de reciprocidade entre os participantes. Assim sendo, para Bakhtin (2011), como as possibilidades da atividade humana são inesgotáveis, os gêneros do discurso, orais ou escritos, são infinitos, ricos e diversos, além de heterogêneos. À medida que cada grupo social, em cada campo da atividade humana, transforma-se, transformam-se os gêneros, uns mais padronizados, outros mais livres, pois são formas de organizar o enunciado e sua ação social, embora isto tenha sido visto muitas vezes de forma equivocada.

Os gêneros discursivos são, por conseguinte, “[...] correias de transmissão entre a história da sociedade e a história da linguagem” (BAKHTIN, 2011, p. 268). Mas isso náo quer dizer que a individualidade seja anulada. $\mathrm{O}$ enunciado, em qualquer gênero $\mathrm{e}$ em qualquer modalidade, reflete a individualidade do locutor/autor. No entanto, há gêneros mais padronizados, como é o caso dos gêneros secundários que, em geral, requerem a minimização dessa individualidade. Sobre gêneros primários e secundários, descreve Bakhtin (2011, p. 263, grifos nosso):

Não se deve, de modo algum, minimizar a extrema heterogeneidade dos gêneros discursivos e a dificuldade daí advinda de definir a natureza geral do enunciado. Aqui é de especial importância atentar para a diferença essencial entre os gêneros discursivos primários (simples) e secundários (complexos) não se trata de uma diferença funcional. Os gêneros discursivos secundários (complexos - romances, dramas, pesquisas científicas de toda espécie, os grandes gêneros publicísticos, etc) surgem nas condiçóes de um convívio cultural mais complexo e relativamente muito desenvolvido e organizado (predominantemente o escrito) - artístico, científico, sociopolítico, etc. No processo de sua formação eles incorporam e reelaboram diversos gêneros primários (simples), que se formaram nas condiçôes da comunicação discursiva imediata.

Para Bakhtin (2011), é significativa a diferença entre esses gêneros primários, ou simples, ligados à vida cotidiana e predominantes na modalidade oral, e gêneros secundários, ou complexos, ligados à vida cultural mais complexa e predominante na modalidade escrita. Ambos são enunciados concretos, escritos ou orais, relacionados a diferentes campos da atividade humana, que demandam um trabalho sobre o material linguístico concreto. É por isso que as mudanças dos gêneros se interligam às mudanças 
históricas dos estilos de linguagem, pois essas estruturas-tipo ou enunciados-tipo, os gêneros, possuem uma tripla composição: o estilo, o tema e a composiçáo ou tipo de construção do conjunto.

Segundo Voloshinov (1981), o que há são os tipos de comunicação social, sendo eles: relações de produção (nas fábricas, por exemplo), relações de negócio (nos organismos públicos, por exemplo), relaçôes quotidianas (encontros em bares, por exemplo) e relaçóes ideológicas stricto sensu (na escola e na ciência, por exemplo). Dessa maneira, reforça-se que é preciso considerar a situaçáo e o auditório: a primeira como a realização concreta de uma variação de umas dessas relaçóes apontadas por Voloshinov (1981); o segundo como a presença dos que fazem parte de uma situação, os interlocutores. Para Bakhtin (2010a), a situação (ou a situação social mais imediata) e os participantes (o meio social mais amplo) determinam a forma e o estilo da enunciação, a sua estrutura, o seu gênero discursivo.

Os gêneros, então, possuem um destinatário situado no campo da atividade humana a que o enunciado se reporta, enunciado este que possui, portanto, um endereçamento e que pressupóe uma atitude responsiva ativa. Ao produzir/realizar um gênero, o sujeito do discurso antecipa uma atitude responsiva - o fundo aperceptivel da percepção do discurso - a partir de sua própria maneira ativa de construir o enunciado. Essa consideração aperceptível da percepção determina a escolha do gênero e do estilo do enunciado, seus procedimentos composicionais e seus meios linguísticos. Considera-se, assim, o grau de proximidade, as visóes de mundo do destinatário, sua posição social etc. Em vista disso, é necessário dominar os gêneros para poder empregálos, porquanto, segundo Bakhtin (2011), apenas quando se dominam os gêneros, consegue-se empregá-los com liberdade, imprimindo-lhes a subjetividade possível e necessária de quem os enuncia. Aqui, retoma-se a importante discussão acerca do dialogismo bakhtiniano que, ao valorizar o estudo dos gêneros, tem, teóricometodologicamente, recursos para investigar, por exemplo, o hibridismo e a pluralidade de sistemas de signos numa determinada cultura.

De fato, não se aprendem os gêneros em manuais ou dicionários, prática ainda comum na educação formal, por exemplo, mas se aprende sim nos processos interativos concretos com os sujeitos reais. Rodrigues (2014) buscou entender de que maneiras os gêneros, como megainstrumentos didáticos, têm sido abordados por professores em escolas municipais de Niterói (RJ), e concluiu que há uma simplificação desse trabalho transportando-se ensino da escrita muito mais para os manuais do que para a vida e para os sujeitos históricos, ainda que a Teoria da Enunciaçáo chegue às escolas via livros didáticos ou via cursos de formação inicial e continuada. 
O diálogo é metodologia de análise dos gêneros, pois estes se desenrolam na dialogia dos signos e dos códigos culturais. As palavras, como signos que são, têm, portanto, materialidade/essência no ideológico, inscritas num espaço heterogêneo, trabalhadas e deslocadas na interaçáo cotidiana entre os sujeitos. Nesse contexto, os sistemas de signos - a palavra é um signo -, além de sua dupla materialidade, são produzidos como signos ideológicos por também representarem a realidade de um lugar valorativo. A escolha das palavras, como veículos de índices de valor, compóe, portanto, um dos mecanismos de constituição dos gêneros discursivos.

Em síntese, se toda vez que se fala ou que se escreve, em qualquer situação, inclusive na escola, produz-se um gênero, toma-se consciência dos entremeios desse debate. Essas estruturas-enunciados dinâmicas condicionam, de certa forma, as escolhas dos sujeitos e por eles são moldadas no curso da interação verbal como guias para os interlocutores. Elas limitam e, do mesmo modo, libertam a atividade comunicativa. Então, intencionalmente ou não, quando se trata da relação linguagem e educação escolar, é fato que lá, no chão da escola, estão os gêneros sendo produzidos em todos os tempos e espaços, por todos os atores sociais, mesmo que o ensino formal da língua camufle essa constatação.

A linguagem, cuja natureza social não se pode mais desconsiderar, caracteriza o ser humano, por fim, e a ela, os gêneros - historicamente situados e organicamente sociais e culturais - são inerentes, inobstante mais ou menos estáveis, heterogêneos, mutáveis e incontáveis. Mas os gêneros são compósitos de signos cuja materialidade/essência está no ideológico, pois o signo é ideológico.

\section{Ideologia: um debate necessário}

O sr. Keuner tinha pouco conhecimento dos homens. Ele dizia: "Conhecimento dos homens só é necessário quando há exploração. Pensar significa transformar. Quando penso em alguém eu o transformo, quase me parece que ele não é absolutamente como é, mas que passou a ser assim quando comecei a pensar sobre ele”. (BRECHT, 2006, p. 70).

Pensar é transformar, mas pensar é concreto, é ação humana cuja expressão se delineia de fora para dentro, sem excetuar uma coloração individual influenciada/influenciável pelo coletivo social em interação. Pensar é enunciar dialogicamente, porque até o discurso interior é dialógico, é recheado de vozes alheias, porque o enunciado alude à interação entre um $\mathrm{eu}$, um outro e um objeto, pois até o discurso interior se constitui de gêneros discursivos carregados de signos ideológicos em constante devir. 
No debate proposto neste artigo, dentre os inúmeros conceitos bakhtinianos, não se pôde negar um interesse especial pela compreensão do conceito de ideologia, tema já estudado por Rodrigues (2010) em sua dissertaçáo de mestrado. Segundo Miotello (2012), Bakhtin e o Círculo aprofundaram questôes de Marx e Engels, principalmente a ideologia, não como subjetiva/interiorizada ou como idealista/psicologizada, mas sim construída no movimento dialético de instabilidade e estabilidade entre uma ideologia oficial (IO) e uma ideologia do cotidiano (IC) em íntima relação: a primeira, por um lado, como a dominante, visto que procura implantar uma única concepção de produção do mundo/da vida; a segunda, por outro, como a que se desenvolve nas interaçóes sociais do dia a dia/nas relaçóes de proximidade social.

É fato que o fenômeno ideológico se materializa na linguagem e é mais facilmente reconhecido através do olhar atento sobre a palavra em sua dupla materialidade: como signo físico-material e como signo sócio-histórico, pois os sistemas de signos, além dessa dupla materialidade, são produzidos como signos ideológicos que refletem e refratam a realidade. Levam-se em conta, então, dois pressupostos: (a) é o universo de signos o conjunto de signos de um grupo social ou de uma classe social; (b) é pelas palavras (portanto, pelos signos), produzindo gêneros discursivos, que os sujeitos representam o mundo.

Assim, o signo é corpo material do corpo social que reflete e refrata a realidade, princípio dialético. Os signos são ideologizados na apreensão do real como representaçôes, a forma como os sujeitos apreendem o vivido e o circunscrevem, são a amostra das transformaçôes sociais. As palavras, como signos, são tecidas a partir de uma multidão de fios ideológicos disponíveis nas relaçôes sociais, nas interaçôes verbais. Para Bakhtin (2010a, p. 42), "[...] a palavra será sempre o indicador mais sensível de todas as transformaçôes sociais, mesmo daquelas que apenas despontam, que ainda náo tomaram forma, que ainda não abriram caminho para sistemas ideológicos estruturados e bem-formados".

Nesse sentido, o produto ideológico, que é um signo, reflete (sendo-lhe fiel como uma sombra da realidade) e refrata (distorce a realidade), tem um significado e remete a algo que lhe é exterior, mas é, consoante Bakhtin (2010a), um fragmento material dessa realidade, tendo em vista que sua realidade é objetiva e, dessa forma, é passível de um estudo metodológico unitário e objetivo (BAKHTIN, 2010b). Aqui, vale acrescentar uma referência à obra $A$ Cultura Popular na Idade Média e no Renascimento, em que Bakhtin (2010b), tratando do riso na obra de Rabelais, expóe que, embora a cultura cômica popular seja infinita e heterogênea em suas manifestaçôes, é possível revelar a unidade, o sentido e a natureza ideológica, ou seja, o seu valor como concepção de mundo. E ele o faz revelando a unidade interna de todos 
os elementos heterogêneos, transportando-se ao próprio terreno onde tal cultura foi (re)produzida.

Como a ideologia, portanto, reflete e refrata a realidade, ao signo ideológico é conferido um caráter intangível que abafa a luta de classes, porque à ideologia dominante se confere um discurso único, monovalente, que, promovido pela classe dominante, procura configurar-se como supraclasses. Para Bakhtin (2010a), há uma relaçáo recíproca e dialética entre infraestrutura e superestrutura, náo no sentido vertical. Nesse sentido, Zandwais (2009, p. 104) aponta que:

Ao afirmar que estáo interessados, notadamente, em tratar do modo como "a realidade (infraestrutura) determina o signo e como este reflete e refrata a realidade em transformação", Bakhtin/Voloshinov estão buscando caracterizar não somente a ubiquidade da palavra, mas, principalmente as formas por meio das quais ela é apropriada, circula e significa no seio dos grupos, nas relaçôes institucionais, formais, ou ainda nas relaçôes informais, no cotidiano da sociedade e da vida do povo soviético. E optam por investigar a realidade da linguagem a partir da infraestrutura, já que, segundo eles, "a palavra penetra literalmente em todas as relaçóes entre os indivíduos, nas relaçóes de colaboração, nos encontros fortuitos da vida cotidiana, nas relaçóes de caráter político".

Mikhail Bakhtin e o Círculo criticavam as interpretações mecanicistas entre infraestrutura e superestrutura e buscavam interpretações de fato marxistas, segundo Zandwais (2009), dando um contorno mais bem acabado ao fenômeno da ideologia, não mais entendida como ocultação ou distorçáo da realidade, como foi interpretado tal conceito a partir de leituras feitas acerca da obra A Ideologia Alemã (MARX; ENGELS, 2007). Nesse texto, os autores sustentam que a ideologia é falsa consciência sim, mas essa tese tem base material, não limitada a tendências idealistas; e nesse caminho também está a discussão bakhtiniana ao reforçar a inextricável relação entre o signo ideológico e a realidade concreta.

Por isso, os intelectuais do Círculo criam o que passou a chamar ideologia do cotidiano (IC) e ideologia oficial (IO) apenas como mecanismos didáticos para a compreensão do fenômeno ideológico e não como duas esferas apartadas, mas sim intercambiáveis e interpenetráveis, confrontando-se e alimentando-se uma à outra. No caso, os sistemas ideológicos estáveis e enformados (a moral, a ciência, a arte e a religião, por exemplo) crescem e se transformam em IC - elemento ideológico instável ou, mais especificamente, discurso interior e exterior. Entretanto, esta transforma aqueles, num elo orgânico vivo, não obstante sofra uma poderosa influência inversa da ideologia 
enformada, como argumenta Bakhtin (2010a, 2012) e como se tenta representar, de modo bastante simples, na Figura 1.

\section{Figura 1 - Relaçáo orgânica: Ideologia do Cotidiano - Ideologia Oficial}

Fonte: Rodrigues (2014).

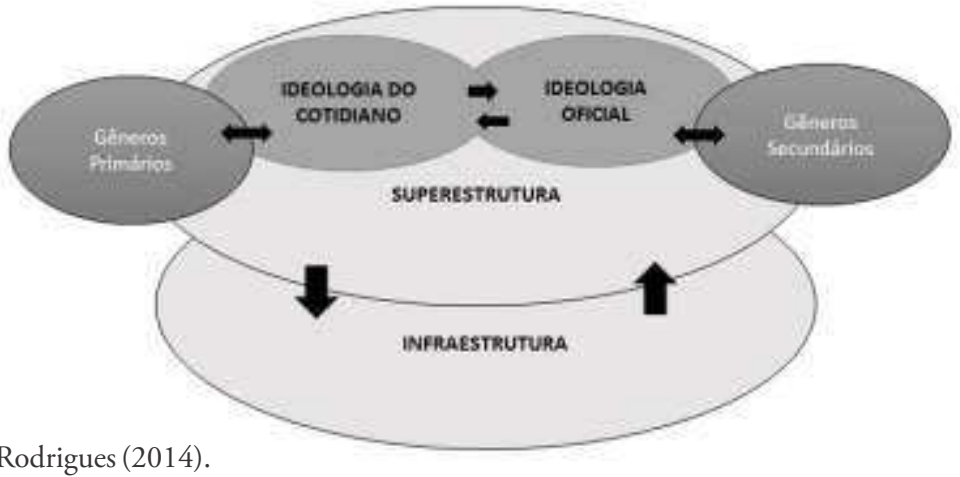

Bakhtin (2010b), mostrando como a estrutura e a superestrutura se intercambiam na Literatura, quando do estudo da obra de Rabelais, explica que até o riso tem valor de concepção de mundo e exprime uma verdade sobre a vida, até porque toca em questóes subsumidas na sisudez da Igreja e do Estado. O riso, para ele, ao qual se reserva um lugar mais baixo na sociedade, o lugar do extraoficial, está muito mais presente na IC, que é a base da sociedade da tradição. Nesse viés, a IO se apropria da IC, fazendo os gêneros discursivos transitarem e influenciarem uns aos outros, e "rouba" o seu discurso, assim como fora feito com o riso, roubado pela seriedade da orientação burguesa, contido, regrado (BAKHTIN, 2010b).

Dessa maneira, no "espaço" da IC aprofundam-se as contradiçóes que rompem, penetram e transformam a IO, ainda que esta seja forte e determinante. Por isso é que, nesse caso, vale a pena lembrar-se do riso popular da Idade Média que, liberto na boca do povo e mais presente na IC, é também expressão das possibilidades de se pensar uma nova realidade, é forma de libertação da consciência do homem.

A riquissima cultura popular do riso na Idade Média viveu e desenvolveu-se fora da esfera social da ideologia e da literatura elevada. Efoi graças a essa existência extraoficial que a cultura do riso se distinguiu por seu radicalismo e por sua liberdade excepcionais, por sua implacável lucidez. Ao proibir que o riso tivesse acesso a qualquer domínio oficial da vida e das ideias, a Idade Média lhe conferiu em compensação privilégios excepcionais de licença e impunidade fora desses limites: na praça pública, durante as festas, na literatura recreativa. (BAKHTIN, 2010b, p. 62, grifo nosso). 
Em síntese, a hierarquia que orienta as ideologias, com uma IO e uma IC, acaba por orientar a hierarquização dos gêneros. A IC está mais presente nos gêneros primários, enquanto a IO está, portanto, nos gêneros secundários; a IC é dominada pela $\mathrm{IO}$, assim como o riso, pertencente ao povo e ligado a certa verdade popular não oficial, na transformação da Idade Média para o Renascimento, fora dominado pela seriedade do aspecto oficial, estatal e religioso historicamente determinado.

Os sistemas ideológicos, na forma de $\mathrm{IO}$, exercem fortíssima influência inversa sobre a IC e, na maior parte das vezes, dão-lhes um tom dominante, embora, segundo Miotello (2012), a IC seja o nascedouro mais primário da ideologia e a mudança, nesse nível, seja lenta, pois o signo ideológico possui sempre um núcleo rígido e relutante. Destarte, a IO é aquela que, como passou pela objetivação social, é mais aceita e mais estabilizada, já que respaldada pela ciência, pelo direito e pela classe dominante, por exemplo, sobrepondo-se à IC. Mais que isso, ao encontro do debate de Marx e Engels (2007):

[...] no decorrer da luta, no curso do processo de infiltração progressiva nas instituiçóes ideológicas (a imprensa, a literatura, a ciência), essas novas correntes da ideologia do cotidiano, por mais revolucionárias que sejam, submetem-se à influência dos sistemas ideológicos estabelecidos, e assimilam parcialmente as formas, práticas e abordagens ideológicas neles acumulados. (BAKHTIN, 2010a, p. 125).

Como um conjunto de sensaçóes cotidianas, que refletem e refratam a realidade social objetiva, a IC dá significado a cada ato humano, a cada açáo e a cada estado consciente. Como salienta Voloshinov (1993), do oceano instável e mutável da IC, afloram gradualmente as inumeráveis ilhas e continentes dos sistemas ideológicos (a ciência, a filosofia, a arte etc), a modo que há sim uma determinação social - uma determinação de classe ou, em outros termos, um ponto de vista de classe. Numa sociedade desse tipo a luta de classes se dá nas palavras, discursivamente, repercutindo na língua as mais ínfimas mudanças sociais (MIOTELLO, 2012).

Dessa maneira, a IC, enquanto tal, penetra paulatinamente nos sistemas ideológicos/na IO e os renova, ao mesmo tempo em que estes renovam a IC. Bakhtin (2010a), face ao exposto, distingue os sistemas ideológicos constituídos (ciência, religião, literatura, arte, direito etc) e a IC como totalidade mental centrada na vida cotidiana, constituída pelo domínio das palavras interior e exterior, não fixada em um sistema único e guia das açôes e da consciência dos sujeitos.

Os fenômenos ideológicos, por consequência, não podem ser reduzidos a particularidades da consciência e do psiquismo. Tampouco se pode ignorar sua 
especificidade semiótico-ideológica. Segundo Bakhtin (2010a), a consciência, fato socioideológico, só pode surgir pela encarnação material do signo, afinal a consciência é uma ficção fora da realização material. Por isso, a própria compreensão é interindividual, pois os signos surgem na interaçáo entre uma consciência e outra, e o próprio indivíduo é um fenômeno socioideológico, já que o individual é tão social quanto a ideologia - todo signo é social. Nesse debate, vale à pena retomar a crítica de Bakhtin (2012, p. 89) a Freud:

O conteúdo e a composição das camadas não oficiais da ideologia do cotidiano (isto é, o conteúdo e a composição do inconsciente, segundo Freud) são condicionados pela época e por uma classe tanto quanto o são as suas camadas 'censuradas' e os sistemas da ideologia enformada.

Não há separação rígida entre consciência oficial e não oficial, entre consciente e inconsciente, para Bakhtin (2012). Para ele, a IC possui camadas: as camadas oficiais, como campos da IC que exprimem os momentos mais estáveis e dominantes, o que Freud chamaria de consciência; e as camadas não oficiais, como campos mais distantes do sistema estável da ideologia oficial, o que Freud chamaria de inconsciente. A partir desse ponto de vista, o autor considera o cosmicismo (a esfera da magia), o biologismo (a esfera do instinto) e o freudismo (a esfera da sexualidade) três tendências tendenciosas, pois fragmentadoras do mundo burguês.

De fato, ademais, se se renuncia à visão de mundo própria do grupo social ao qual pertence até entáo, é unicamente porque a ideologia de outro grupo social terá investido na consciência do sujeito, tendo-a invadido e obrigado ao reconhecimento da legitimidade da realidade social que a produziu. Assim, consciência é também realidade concreta, porque pode materializar-se como signo, o qual tem aspecto ideológico, pois o sujeito entende a realidade material pela exteriorização do signo preenchido de sentidos. Em síntese, a consciência está impregnada de conteúdo ideológico que não pode ser explicado fora das relações de produção. Nesse viés, autoconsciência é consciência de classe (BAKHTIN, 2012).

Numa relação cujos intermediários são os signos, é a interligação constante entre infraestrutura e superestrutura que gera as ideologias que tanto reproduzem e mantêm a ordem social quanto discutem e subvertem as relaçóes dadas nesse contexto. No interior de qualquer sociedade, e no interior das instituiçôes que dela fazem parte, como é o caso da escola, o modo de produção material da vida cria vínculos diferentes entre os sujeitos, e é na apreensão das contradiçôes inerentes à vida material que as consciências, e nela o signo ideológico como força material, podem ser explicadas, embora seus sentidos sejam heterogêneos devido às diferentes e desiguais formas de 
relaçấo entre os sujeitos e os modos de produção. É o horizonte social que determina, portanto, a criação ideológica dos grupos. Vale enfatizar que, para Bakhtin (2012), nem todo o discurso que náo se verbaliza perece, visto que, pelo contrário, pode mover-se como luta contra a IO, caso alinhado à existência socioeconômica de todo um grupo social.

\section{Apontamentos finais}

Aqui, longe de pôr fim a essa contenda, faz-se um retorno ao texto Se os tubaróes fossem homens (BRECHT, 2006), uma comparação entre uma civilização de homens e uma de tubarôes e peixes vazada pelas relaçôes entre a infraestrutura, como produçấo material da vida social, e a superestrutura, como lócus das diversas ideologias (a IC e a IO). Nessa pequenina história, os professores-peixinhos, num contexto realimaginário, funcionam como sujeitos que lançam mão de um universo de signos para a manutenção das escolas-gaiolas, da sociedade-mar, produzindo e reproduzindo uma ideologia dominante, veiculada por gêneros discursivos todo o tempo.

Essa alegoria da escola retoma a tese de doutorado de Rodrigues (2014). Para os professores participantes da pesquisa, a possibilidade do enfrentamento dessa sociedade de tubarôes, pela busca de condiçôes mais igualitárias entre os cidadãos, é quase nula. É a participação social do aluno como um "bom cidadão", o que faz recordar a formação moral dos peixinhos que docilmente estudam em grandes gaiolas, a meta da formação crítica por meio do ensino da produção textual escrita. Entretanto, toda palavra (todo signo) reflete e refrata a realidade, é um fragmento material dela e não é uníssona, e por meio dela se criam ranhuras, brechas, possibilidades de produção (nem sempre reprodução) material e não material da vida.

Como analisado por Bakhtin (2010b), o realismo grotesco - e nele enquadra Bertold Brecht -, a datar da deformidade, instiga a perspectiva da transformação, como a análise que faz acerca do riso e da carnavalização na Idade Média e no Renascimento:

Na realidade, a função do grotesco é liberar o homem das formas de necessidade inumana em que se baseiam as ideias dominantes sobre o mundo. [...] O riso e a visão carnavalesca do mundo, que estão na base do grotesco, destroem a seriedade unilateral e as pretensóes de significação incondicional e intemporal e liberam a consciência, o pensamento e a imaginação humana, que ficam assim disponíveis para o desenvolvimento de novas possibilidades. (BAKHTIN, 2010b, p. 43, grifo nosso).

Na quebra da imobilidade fictícia do mundo existente, o autor pensa o grotesco como motivo à mudança possível e necessária à realidade concreta 
desumana/desumanizante, como forma de liberação/libertação dos seres humanos, despindo-os e mascarando-os (porque a máscara é a revelação do grotesco), driblando a ideologia oficial-dominante e pondo em seu lugar a alegria da reencarnação sob a forma de ideologias cotidianas de novo tipo, quem sabe, revolucionárias.

A lição de Bakhtin e de Brecht - este cuja produção se situa no realismo grotesco; aquele cuja análise se dá sobre o grotesco - passa no seio da linguagem (no seio da natureza social da linguagem) e na perspectiva do materialismo histórico e dialético (porque a palavra tem força material), e essa relação merece, sem dúvida, estudos mais aprofundados. Em Bakhtin (2011), por exemplo, no oxímoro memória de futuro ${ }^{4}$, está o debate proposto: não se desconsidera o passado, a memória de passado (as ideologias), mas provoca-se uma orientação para o futuro, um desejo de futuro, um futuro transformado, novo, utópico, que orienta o presente. A figura do deus Jano, ou Janus, deus romano das passagens e dos portóes, figura de duas faces, com um rosto virado para o passado e o outro para o futuro, representa essa memória de futuro. Para Bakhtin (2010b), essa figura alude à alternância e à renovaçáo, pois se trata do deus dos recomeços, contrário à imobilidade conservadora. Fala-se aqui da ideia de que o ser humano está de uma determinada maneira, e náo de que ele é embrutecido, petrificado, imutável. $\mathrm{Na}$ carnavalizaçấo e no grotesco, o autor incita que a vida se revela na ambivalência, na alternância e na renovação, social e historicamente.

Numa abordagem macroanalítica, Bakhtin contribui com análises quase consensuais entre pesquisadores da área de linguagem nas várias perspectivas teóricas existentes no Brasil e no mundo, como é o caso da Linguística Textual, segundo reitera Marcuschi (2008). Enfim, fornece subsídios teóricos de grande valia não só para esse campo, mas também em sua interlocução com a educação (KRAMER, 2004; MELLO, 2011; BRAIT, 2013; GOULART, 2014; RODRIGUES, 2014), como se discutiu aqui sumariamente, "começando" na discussão acerca da linguagem (que é social, não é aprendida em manuais, como ainda se vê na educaçáo formal) e "encerrando" com o conceito de ideologia presente nos gêneros discursos (que são gêneros da vida, das práticas sociais, questão cara ao ensino de línguas), na imbricação de elos contínuos, inextricáveis. Espera-se, portanto, ter contribuído com esse debate e incitado sua continuidade.

\section{Notas}

${ }^{1}$ Melo (2006, p. 129) explica: "Keuner torna-se um companheiro constante de Brecht. Seu nome pode ser explicado por duas vias: pelo termo grego koinós, 'o que diz respeito a todos' - que se configura como ninguém em particular -, ou pela palavra keiner, 'ninguém', que se pronuncia 'koiner' no dialeto suábio alemão". 
${ }^{2}$ No romance monológico, todo o processo de criaçáo se resume ao autor, pois as personagens não têm voz. Consoante Bezerra (2012), o romance tradicional, monofônico, nega a isonomia entre as consciências, visto que as personagens são tomadas como objeto do discurso do autor, como coisas, e não sujeitos. No romance polifônico, de base dialógica, as personagens, como explicam Ferreira e Aquino (2008), são construídas no decorrer da obra, como num processo evolutivo, e ganham autonomia, construindo seus próprios discursos.

${ }^{3}$ Esse universo de signos é o conjunto de signos de um determinado grupo social.

${ }^{4}$ Geraldi (2009) interpreta a memória do futuro (utopias) e a memória do passado (ideologias) como memórias ou visóes sociais de mundo (LÖWY, 1988) que se movimentam dialeticamente.

\section{REFERÊNCIAS}

BAKHTIN, Mikhail. Marxismo e filosofia da linguagem: problemas fundamentais do método sociológico da linguagem. 14. ed. São Paulo: Hucitec, 2010a.

BAKHTIN, Mikhail. A cultura popular na idade média e no renascimento: o contexto de François Rabelais. 7. ed. São Paulo: Hucitec, 2010b.

BAKHTIN, Mikhail. Estética da criação verbal. 6. ed. São Paulo: WMF Martins Fontes, 2011.

BAKHTIN, Mikhail. O freudismo: um esboço crítico. 2. ed. São Paulo: Perspectiva, 2012.

BAKHTIN, Mikhail. Problemas da poética de Dostoiévski. 5. ed. Rio de Janeiro: Forense Universitária, 2013.

BEZERRA, Paulo. Polifonia. In: BRAIT, Beth (Org.). Bakhtin: conceitos-chave. 5. ed. São Paulo: Contexto, 2012. p. 191-200.

BEZERRA, Paulo. Prefácio: uma obra à prova do tempo. In: BAKHTIN, Mikhail. Problemas da poética de Dostoiévski. 5. ed. Rio de Janeiro: Forense Universitária, 2013. p. V-XXII.

BRAIT, Beth. Inovação e tradição em diálogo no ensino de gramática em livros didáticos. Eutomia, Recife, v. 1, p. 312-38, 2013.

BRAIT, Beth; MELO, Rosineide de. Enunciado/enunciado concreto/enunciação. In: BRAIT, Beth (Org.). Bakhtin: conceitos-chave. 5. ed. São Paulo: Contexto, 2012. p. 61-78.

BRECHT, Bertold. Histórias do sr. Keuner. Tradução de Paulo César de Souza. São Paulo: Editora 34, 2006. 
CASTRO, Gilberto de. Formas sintáticas de enunciação: o problema do discurso citado no Círculo de Bakhtin. In: BRAIT, Beth (Org.). Bakhtin e o Círculo. São Paulo: Contexto, 2009. p. 117-135.

FERREIRA, João Batista Diniz; AQUINO, Jefferson Alves de. A gênese da polifonia em Dostoiévski. Homem, Espaço e Tempo, Sobral, CE , ano 2, n. 1, mar. 2008.

GERALDI, João Wanderley. Linguagem e ensino: exercícios de militância e divulgação. 2. ed. São Paulo: Mercado de Letras, 2009.

GOULART, Cecília. O conceito de letramento em questão: por uma perspectiva discursiva da alfabetização. Bakhtiniana, São Paulo, v. 9, n. 2, p. 35-51, ago./dez. 2014.

KRAMER, Sônia. Professoras de educação infantil e mudança: reflexões a partir de Bakhtin. Cadernos de Pesquisa, São Paulo, v. 34, n. 122, p. 497-515, maio/ago. 2004 .

LÖWY, Michael. Ideologias e ciência social: elementos para uma análise marxista. 4. ed. São Paulo: Cortez, 1988.

MACHADO, Irene. Gêneros discursivos. In: BRAIT, Beth (Org.). Bakhtin: conceitos-chave. 5. ed. São Paulo: Contexto, 2012. p. 151-166.

MARCUSCHI, Luiz Antônio. Produção textual, análise de gêneros e compreensão. São Paulo: Parábola, 2008.

MARX, Karl; ENGELS, Friedrich. A ideologia alemã: crítica da mais recente filosofia alemã em seus representantes Feuerbach, B. Bauer e Stirner, e do socialismo alemão em seus diferentes profetas (1845-1846). São Paulo: Boitempo, 2007.

MELLO, Marisol Barenco. Inclusão ou diálogos na escola: uma experiência de formação de professoras. Teias, Rio de Janeiro, v. 12, p. 57-66, 2011.

MELO, Vilma Botrel Coutinho de. "A verdade, minha casa e meu carro! In: BRECHT, Bertold. Histórias do sr. Keuner. Tradução de Paulo César de Souza. São Paulo: Editora 34, 2006. p. 125-135.

MIOTELLO, Valdemir. Ideologia. In: BRAIT, Beth (Org.). Bakhtin: conceitoschave. 5. ed. São Paulo: Contexto, 2012. p. 167-190.

RODRIGUES, Jéssica do Nascimento. Das concepçôes prévias aos sentidos construidos na formação crítica do educador ambiental. 2010. 128f. (Mestrado em Educação) Universidade Federal Rural do Rio de Janeiro, Seropédica, RJ, 2010. 
RODRIGUES, Jéssica do Nascimento. A produção de textos escritos na formação de sujeitos críticos letrados: o trabalho dos professores de Língua Portuguesa em foco. 2014. 450f. (Doutorado em Educação) - Universidade Federal Fluminense, Niterói, RJ, 2014.

VOLOSHINOV, Valentin Nikolaevich. Estrutura do Enunciado. Tradução de Ana Vaz. In: TODOROV, Tzevan. Mikhail Bakhtin: le príncipe dialogique. Paris: Seuil, 1981. p. 1-19.

VOLOSHINOV, Valentin Nikolaevich. ¿Que és el linguaje? In: SILVESTRI, Adriana; BLANCK, Guilhermo. Bajtín y Vigotski: la organización semiótica de la conciencia. Barcelona: Anthropos, 1993. p. 217-243.

ZANDWAIS, Ana. Bakhtin. Voloshinov: condiçôes de produção de Marxismo e filosofia da linguagem. In: BRAIT, Beth (Org.). Bakhtin e o Círculo. São Paulo: Contexto, 2009. p. 97-116. 


\section{From language to ideology: Del lenguaje a la ideología: Bakhtinian contributions contribuciones bakhtinianos}

\begin{abstract}
In this article, substantially grounded in Bakhtin, the objective is to perform a theoretical study, by literature review, about some fundamental concepts - language, enunciation, discursive genre and ideology - showing their inseparability. In the first section, we present the assumption that language is originally social, while the idiom, a socio-historical product, is constantly changing. In the second one, we debate the concept of enunciation as text, oral or written, concrete, which constitutes and organizes collective life. In the third one, we touch the theme of discursive genres, historically situated and organically social and cultural. In the last section, we develop the concept of ideology in constant connection between infrastructure and superstructure, between the everyday and official ideology. Lastly, we discuss, as a backdrop, the possible ethical and organic involvement of humans with the reality of life and with others.
\end{abstract}

Keywords: Language. Discursive Genre. Ideology.

\section{Resumen}

En este artículo, basado sustancialmente en Bakhtin, objetiva realizar un estudio teórico de revisión de la literatura acerca de algunos conceptos fundamentales - elocución lenguaje, género discursivo e ideología - mostrando su inseparabilidad. En la primera sección, se presenta el presupuesto de que el lenguaje es un originalmente social, y la lengua, un producto histórico-social en constante cambio. En la segunda, se debate el concepto de enunciado como forma de texto, oral o escrito, concreto, que constituye y organiza la vida colectiva. En la tercera sección, abordamos el tema de los géneros discursivos históricamente situados y orgánicamente sociales y culturales, para de este modo, en la última sección, desarrollar el concepto de ideología en relación constante entre infraestructura y superestructura, entre la ideología del cotidiano y la oficial. Por último, se discute, como telón de fondo, la posible implicación ética y orgánica de los seres humanos con la realidad de la vida y con los demás.

Palabras claves: Lenguaje. Género Discursivo. Ideologia. 
Jéssica Nascimento Rodrigues

E-mail: jessicarbs@gmail.com

\section{Mary Rangel}

E-mail: mary.rangel@lasalle.org.br

Recebido em: 21/12/2014 Aprovado em: 3/6/2015 